\title{
Spectrum of Dermatological Manifestations among Travelers Presenting at a Travel Medicine Center in Western Nepal
}

\author{
Gupta $\mathbf{S}^{1}$, Pokhrel $\mathbf{S}^{1}$, Neupane $\mathbf{S}^{2}$, Pandey $\mathbf{P}^{1}$ \\ ${ }^{1}$ CIWEC Hospital, Travel Medicine Center, Pokhara, Nepal, ${ }^{2}$ Gandaki Medical College Teaching Hospital, Pokhara, \\ Nepal
}

\begin{abstract}
Introduction: Skin disorders are among the most common reasons for travelers to seek medical care during and after travel. There is limited data on the spectrum of dermatoses reported among travelers during travel especially in South Asian continent.

Objective: To review the spectrum of skin disorder manifested among the traveler population attending a travel medicine hospital in western Nepal.

Materials and Methods: We performed a prospective study of the travelers visiting The Canadian International Water and Energy Consultants (CIWEC) Hospital, and Travel Medicine Center in Pokhara with history of skin disorders. This study was done from September 2014 until December 2015.

Results: A total of 130 (14.7\%) patients presenting with dermatological manifestations were enrolled in the study. The most common diagnoses were bacterial skin infections $20.4 \%$, arthropod bites $13.6 \%$ followed by animal bites and skin laceration due to trauma,each were $12.1 \%$. Among patients with bacterial skin and soft tissue infections, pus culture and sensitivity were recorded in 13 patients. In almost fifty percent of our sample Staphylococcus aureus growth was seen, of which $38.5 \%$ were Methicillin Resistant Staphylococcus aureus.

Conclusion: Bacterial skin and soft tissue infections, arthropod bites and animal bites were common reasons for travelers to seek medical consultations during travel in Nepal. This information will be useful for the medicine professionals while taking care of travelers and also while providing pre-travel consultation to the prospective travelers.
\end{abstract}

Key words: Nepal; Skin diseases; Staphylococcus aureus; Travel medicine

\section{Introduction}

$\mathrm{D}$ ermatological problems are among the leading causes of morbidity in travelers seeking medical care during or after return from international travel. ${ }^{1}$ The GeoSentinel Surveillance Network of globally dispersed travel or tropical medicine clinics have reported dermatological problems to range from $17 \%$ to $19.5 \%$ of diagnoses and have been ranked third after fever and diarrheal illness. ${ }^{2,3}$ These studies showed that most commonly diagnosed dermatological diseases were skin or soft tissue infections, insect bite, rash and animal bites.

Dermatoses were diagnosed in up to $23.4 \%$ of travelers returning to a health center in France. ${ }^{4}$ In American travelers, skin diseases have been reported in $8 \%$ of

Address of Correspondence:

Dr. Sandeep Gupta, MD, CTH

General Practitioner

CIWEC Hospital-Travel Medicine Center, Mansarovar Path, Lake side-6, Pokhara, Nepal.

E-mail: sandeep140@hotmail.com travelers to developing countries. ${ }^{5}$ In three studies from Nepal, travelers presenting with skin diseases have ranged from 9 to $12 \%$, making dermatoses a leading cause for seeking medical consultation during their stay in Nepal. ${ }^{6-8}$

Nepal is a well known tourist destination in SouthAsian region. There has been increasing numbers

Submitted: $15^{\text {th }}$ December 2018

Accepted: $9^{\text {th }}$ February 2019

Published: $31^{\text {st }}$ March 2019

How to cite this article

Gupta S, Pokhrel S, Neupane S, Pandey P. Spectrum of dermatological manifestations among travelers presenting at a travel medicine center in Western Nepal. Nepal Journal of Dermatology, Venereology and Leprology. 2019;17(1):58-62. doi: http://dx.doi.org/10.3126/njdvl.v17i1.23386

\section{(c) (i)}

Licensed under CC BY 4.0 International License which permits use, distribution and reproduction in any medium, provided the original work is properly cited. 
with over 600,000 non-Indian tourists arriving each year. Approximately, 100,000 travelers visit Nepal for trekking. ${ }^{9}$ Data on dermatological disease or injuries experienced by these travelers are limited. This study aimed to characterize the spectrum of skin disorder manifested among traveler population attending travel medicine clinic in Western Nepal.

\section{Materials and Methods}

This was a retrospective study conducted in CIWEC (The Canadian International Water and Energy Consultants) hospital and travel medicine clinic. Prior permission was obtained from institutional review board. The clinical records of all the travelers visiting to the hospital from September 2014 through December 2015 were screened. Out of those records, only the records of patients with dermatological diseases were reviewed. Patients with skin disorders that appeared during travel comprised of the study group. The demographic details of those patients like age, sex, country of origin were recorded in the proforma. And the types of the dermatological problems were also noted. Statistical analysis was performed using SPSS version 17.0 for window.

\section{Results}

During the study period of sixteen months, a total of 917 foreign travelers attended CIWEC Hospital in Pokhara for medical consultation. Number of patients presenting with dermatological manifestations were 130 (14.7\%). The numbers of female patients were 69 (53\%) and male patients were 61 (47\%). Almost sixty seven percentage of our travelers visited Nepal for tourism (Table 1). Patient's age ranged from 18 months to 75 years. The highest number of patients, 64 (49.2\%) were in the age group of 21-30 years followed by 23 $(17.6 \%)$ in the age group of $31-40$ years (Figure 1 ). The majority of travelers were Western European travelers (48\%) followed by North Americans travelers (25.4\%) (Table 2).

The different skin diseases diagnosed are shown in Table 3. The five most common diagnoses were bacterial skin infections (20.4\%), arthropod bite reactions (13.6\%), animal bites and skin laceration due to trauma (12.1\% each) and dermatitis including eczema (11.4\%). Diseases due to environmental factors included frostbite and chilblains. Miscellaneous group comprised of generalized pruritus, corn and diabetic skin lesions. Among patients with bacterial skin and soft tissue infections, pus culture and sensitivity were recorded in 13 out of 27 patients. In almost fifty percent of patients with bacterial infections, Staphylococcus aureus growth was seen, of which $38.5 \%$ were Methicillin Resistant Staphylococcus aureus (MRSA) (Table 4).

Table 1: Traveler's Demographics.

\begin{tabular}{|l|c|}
\hline Patient Visited & 917 \\
\hline Patient Studied (\%) & $130(14.7 \%)$ \\
\hline Mean age (years) \pm S.D & $36.1 \pm 12.32$ \\
\hline Female gender (\%) & $69(53 \%)$ \\
\hline Male gender (\%) & $61(47 \%)$ \\
\hline Purpose Of Travel & \\
\hline Tourism & $88(67.6 \%)$ \\
\hline Business & $8(6.3 \%)$ \\
\hline Volunteer/Research/Missionary & $34(26.1 \%)$ \\
\hline
\end{tabular}

Table 2: Geographical Distribution of Travelers.

\begin{tabular}{|l|l|}
\hline Region & Number of Travelers (\%) \\
\hline Western Europe & $63(48.3 \%)$ \\
\hline North America & $33(25.4 \%)$ \\
\hline Australia/ NZ & $17(13 \%)$ \\
\hline Asian Continent & $14(10.4 \%)$ \\
\hline South America & $3(2.6 \%)$ \\
\hline
\end{tabular}

Table 3: Spectrum of Dermatoses.

\begin{tabular}{|l|c|}
\hline Diagnosis & $\mathbf{n ~ ( \% )}$ \\
\hline Bacterial & $27(20.4 \%)$ \\
\hline Arthropod bite reactions & $18(13.6 \%)$ \\
\hline Animal bite (dog and monkey) & $16(12.9 \%)$ \\
\hline Lacerations and Cuts & $16(12.9 \%)$ \\
\hline Dermatitis /Eczema & $15(11.4 \%)$ \\
\hline Urticaria & $6(4.6 \%)$ \\
\hline Viral Exanthemas & $5(3.8 \%)$ \\
\hline Environmental Problems & $6(4.6 \%)$ \\
\hline Nail Disorders & $9(6.7 \%)$ \\
\hline Fungal Infections & $3(2.3 \%)$ \\
\hline Scabies & $2(1.5 \%)$ \\
\hline Miscellaneous & $7(5.3 \%)$ \\
\hline & $130(100 \%)$ \\
\hline
\end{tabular}

Table 4: Pus culture and sensitivity interpretation.

\begin{tabular}{|l|c|}
\hline Culture Growth & n (\%) \\
\hline $\begin{array}{l}\text { Methicillin Resistant Staphylococcus } \\
\text { aureus }\end{array}$ & $5(38.5 \%)$ \\
\hline Staphylococcus aureus & $2(15.4 \%)$ \\
\hline Klebsiella spp. & $1(7.6 \%)$ \\
\hline No Growth & $5(38.5 \%)$ \\
\hline
\end{tabular}




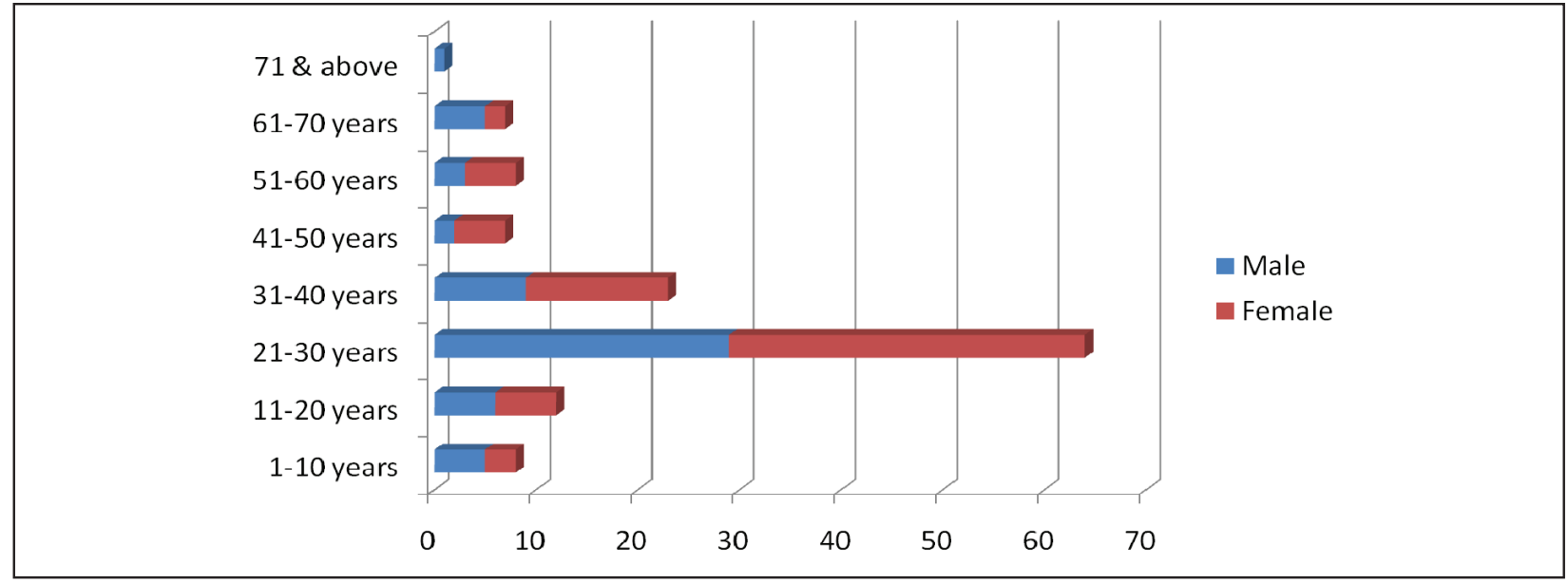

Figure 1: Age-wise distribution of the patients.
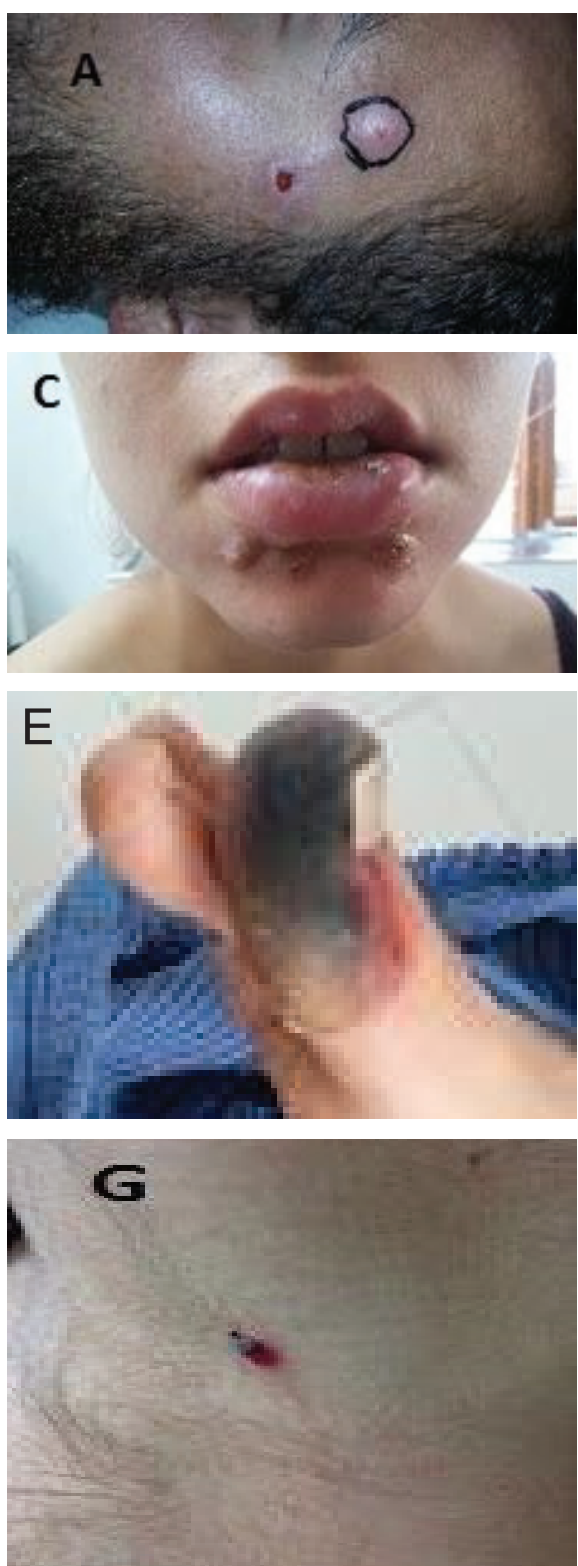
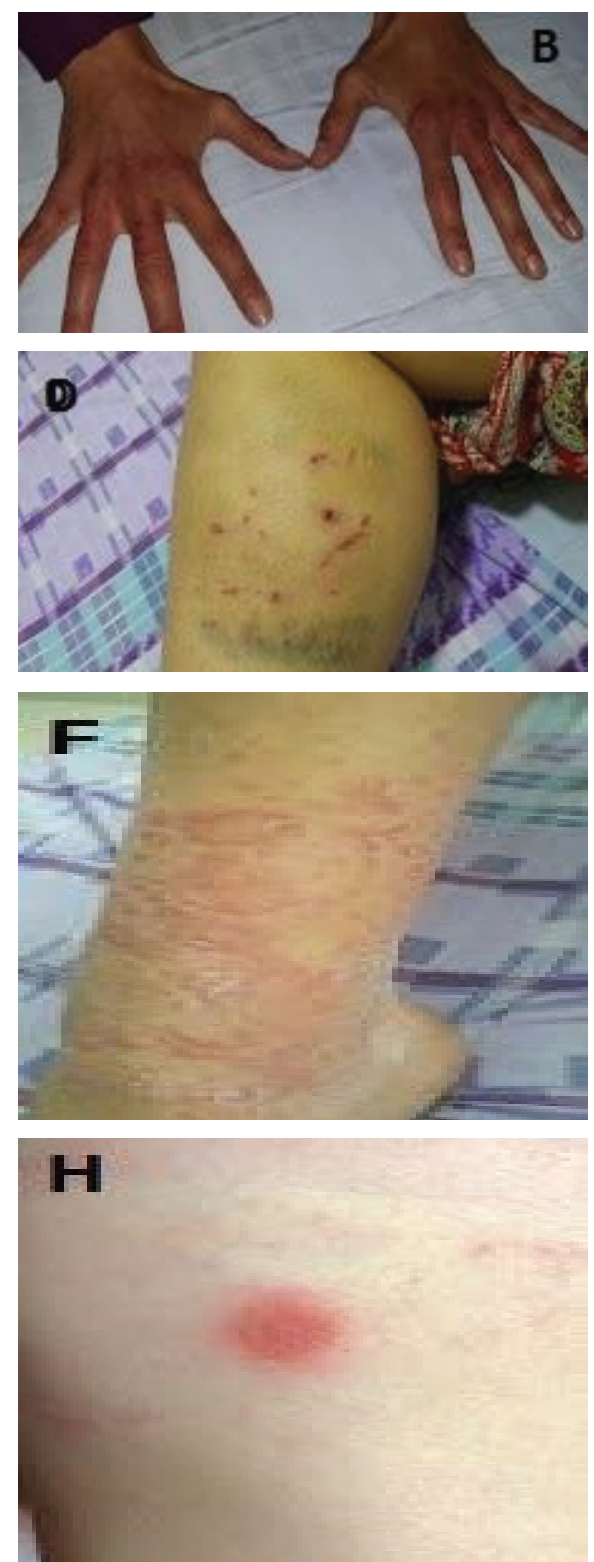

Figure 1 (A) Staphylococus aureus Cellulitis. (B) Chilblains. (C) Herpes Simplex type 1 infection in 22 years old traveler. (D) Dog bite on right leg in 24 year old female traveler. (E) Frostbite on the big toe of 57 year old traveler. (F) Urticarial rash on 23 year old female traveler. (G) Tick seen crawling on armpit on a traveller returning from Chitwan jungle of Nepal. (H) Tick bite lesion on a 34 year old female traveler. 


\section{Discussion}

The current study on dermatoses, is among the few studies done during travel to investigate the pattern of skin diseases in Nepal. Although this study is limited to a single hospital, we believe that the result represents an overall incidence and distribution of skin diseases among travelers visiting within the country.

Travelers are exposed to a variety of health related problems during and after return from travel. ${ }^{5,10}$ Travel epidemiology studies indicate that $22 \%-64 \%$ of travel related health problems are self reported by traveler to developing world and $7-30 \%$ of them consult a physician while abroad. ${ }^{11,12}$

In our hospital, dermatological manifestations were third leading cause of consultation for travelers accounting for $14.7 \%$. The GeoSentineal Surveillance Network study of 2008 showed that $18 \%$ of all patients were diagnosed with dermatological problem after travel. ${ }^{3}$ Another GeoSentinal Surveillance study of Illness on returned travelers 2007-2011 showed skin diseases in $19.5 \% .^{2}$, This shows the increasing trend of travelers seeking medical care for skin diseases. Our study showed that skin diseases were more prominent among female travelers, 53\% females compared to $47 \%$ males. This findings were persistent with CanTravNet Surveillance Network 2009-2012, in which out of the returned Canadian travelers, 58.4\% were females. ${ }^{13}$ In an American study, female travelers comprised of 56\%. ${ }^{5}$ Two GeoSentinel Surveillance Network studies have reported female travelers with skin diseases to be $49.6 \%$ and $53 \%$, respectively. ${ }^{2.3}$

The Global TravEpiNet (GTEN) network data shows 13,235 individuals of age group ranging from 1 month to 94 years (median age 35 years) seek pre-travel health advice across health clinics in United States in 2009 to $2011 .{ }^{14}$ Our study showed travelers age ranged from 18 months to 75 years. The majority of patients (approximately 50\%) in our study were in the age group of $21-30$ years followed by around $18 \%$ in the age group of $31-40$ years. This finding indicates that the majority of young travelers are the common group of population travelling globally. In a study of 4,158 returned travelers at Travel Medicine Clinic, Munich, almost $52 \%$ of travelers belonged to age group of 20-39 years. $^{15}$

The present study showed bacterial skin and soft tissue infection at $20.4 \%$, to be the most common diagnosis followed by arthropod bite reactions, animal bites and skin laceration and dermatitis. These findings were similar with two studies done at French Embassy in 1984 and 2001, which showed bacterial skin infections to be the most common cause of skin disorder among French tourist visiting Nepal. ${ }^{7}$ A study from Israel also showed that bacterial skin infection (reported in 56\%) was the most common tropical infections among Israeli travelers returning from Asian continent. ${ }^{16}$ Two studies by Herbinger $\mathrm{KH}$ et al and Korzeniewski $\mathrm{K}$ et al showed that around $22 \%$ of travelers were diagnosed with bacterial skin disorders. ${ }^{15,17}$

The GeoSentinel Surveillance Network study showed that bacterial skin and soft tissue infections were diagnosed among $16 \%$ of patients and were further categorized as skin abscess in $7.7 \%$, super infected skin in $6.8 \%$ and cellulitis in $1.5 \%{ }^{3}$

In our study, half of the skin and soft tissue infections had a positive growth for Staphylococcus aureus and $38.5 \%$ of these organisms were Methicillin Resistant Staphylococcus aureus. In the study done by Nurjodi D et al, skin and soft tissue infection in travelers in Europe showed that $62 \%$ were positive for Staphylococcus aureus and $11.7 \%$ of them were Methicillin Resistant Staphylococcus aureus infection with predominant travel destinations of these travelers being Africa in $32 \%$ and South East Asia in $28 \%{ }^{18}$

\section{Conclusion}

Dermatological manifestations are common among the traveler population in Western Nepal. Skin diseases like bacterial skin infections, arthropod bite reactions and animal bites were common reasons to seek medical care during travel. Hence, preventive measures should include use of insect repellent, maintenance of good skin hygiene, and avoiding animal bites.

Financial disclosure: None.

Conflict of interest to disclosure: None declared. 


\section{References}

1. O'Brien MB. A practical approach to common skin problems in returning travelers. Travel Med Infect Dis 2009; 7: 125-46. https://doi.org/10.1016/j. tmaid.2009.03.003

2. Leder K, Torresi J, Libman MD, Cramer JP, Castelli F, Schlagenhauf P et al; GeoSentinel Surveillance Network. GeoSentinel surveillance of illness in returned travelers, 2007-2011. Ann Intern Med. 2013;158:456-68. https://doi.org/10.7326/00034819-158-6-201303190-00005

3. Lederman ER, Weld LH, Elyazar IR, von Sonnenburg F, Loutan L, Schwartz E et al; GeoSentinel Surveillance Network. Dermatological conditions in the ill returned traveler: an analysis from the GeoSentinel Surveillance Network. Int J Infect Dis. 2008;12:593-602. https://doi.org/10.1016/j. ijid.2007.12.008

4. Ansart S, Perez L, Vergely O, Danis M, Bricaire $F$, Caumes $E$. Illness in travelers returning from the topics: a prospective study of 622 patients. J Travel Med. 2005;12:312 -18. https://doi. org/10.2310/7060.2005.12603

5. Hill DR. Health problems in a large cohort of Americans travelling to developing countries. J Travel Med. 2000;7:259-66. https://doi. org/10.2310/7060.2000.00075

6. Hochedez P, Caumes E. Common Skin Infections in Travelers. J Travel Med. 2008;15:252-62. https:// doi.org/10.1111/j.1708-8305.2008.00206.x

7. Hochedez $P$, Vinsentini $P$, Ansart $S$, Caumes E. Changes in the pattern of health disorders diagnosed among two cohorts of French travelers to Nepal, 17 years apart. J Travel Med. 2004;11:341-46. https://doi. org/10.2310/7060.2004.19201

8. Shlim D. Learning from experience: travel medicine in Kathmandu. In: Travel medicine 2. Proceedings of the Second Conference on International Travel Medicine. Atlanta, GA: International Society of Travel Medicine, 1992.p.40-48.

9. Ghimire $D R$, Ghimire $S$, Ghimire $N$, Nirula $K P$, Janwali D, Dipak Koirala D(eds.). Nepal Tourism Statistics 2016. Government of Nepal, Ministry of Culture, Tourism and Civil Aviation, Planning and evaluation division, Research \& statistical section. Kathmandu, 2016. Available from: http:// tourism.gov.np/files/statistics/2.pdf [accessed on 20th December 2017].
10. Freedman DO, Weld LH, Robins R, von Sonnenburg $F$, Keystone JS, Pandey $P$ et al. Spectrum of disease and relation to place of exposure among ill returned travelers. N Engl J Med. 2006;354:119-30. https://doi.org/10.1056/ NEJMoa051331

11. Freedman DO. Travel Epidemiology. In: Brunette GW (Ed.). CDC Health Information for International Travel 2017. Oxford University Press, New York 2017.p.8-11.

12. Winer $L$, Alkan M. Incidence and Precipitating Factors of Morbidity among Israeli Travelers Abroad. J Travel Med. 2002;9:227-32. https:// doi.org/10.2310/7060.2002.24202

13. Stevens MS, Geduld J, Libman M, Ward BJ, McCarthy AE, Vincelette J et al. Dermatoses among returned Canadian travelers and immigrants: surveillance report based on CanTravNet data, 2009-2012. CMAJ Open. 2015;3:119-26. https:// doi.org/10.9778/cmajo.20140082

14. LaRocque RC, Rao SR, Lee J, Ansdell V, Yates JA, Schwartz BS et al. Global TravEpiNet: a national consortium of clinics providing care to international travelers - analysis of demographic characteristics, travel destinations, and pretravel healthcare of high-risk US international travelers, 2009-2011. Clin Infect Dis. 2012;54:455-62. https://doi.org/10.1093/cid/cir839

15. Herbinger $\mathrm{KH}$, Siess $\mathrm{C}$, Nothdurft HD, von Sonnenburg F, Löscher T. Skin disorders among travelers returning from tropical and non-tropical countries consulting a travel medicine clinic. Trop Med Int Health. 2011;16:1457-64. https://doi. org/10.1111/j.1365-3156.2011.02840.x

16. Solomon $M$, Benenson S, Baum S, Schwartz E. Tropical Skin Infections Among Israeli Travelers. Am J Trop Med Hyg. 2011;85:868-72. https://doi. org/10.4269/ajtmh.2011.10-0471

17. Krzysztof K, Dariusz J, Jerzemowski J. Skin Lesions in returning travelers. Int Marit Health. 2015;66:173-80. https://doi.org/10.5603/ IMH.2015.0034

18. Nurjadi D, Friedrich-Jänicke B, Schäfer J, Van Genderen PJ, Goorhuis A, Perignon A et al. Skin and soft tissue infections in intercontinental travelers and the import of multi-resistant Staphylococcus aureus to Europe. Clin Microbiol Infect. 2015;21:67-77. https://doi.org/10.1016/j. cmi.2015.01.016. 